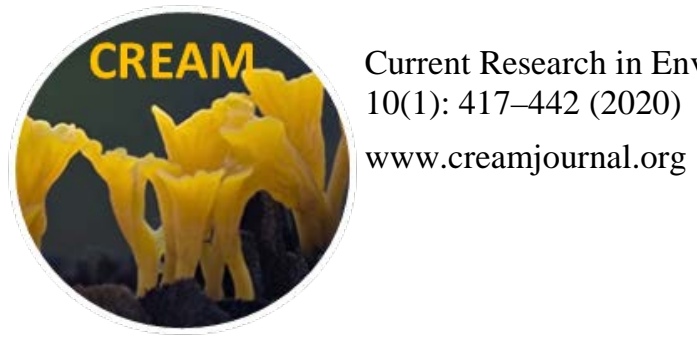

$$
\begin{gathered}
\text { Article } \\
\text { Doi 10.5943/cream/10/1/33 }
\end{gathered}
$$

\title{
Fungal enzymatic degradation of industrial effluents - A review
}

\section{Vara S and Karnena MK}

Department of Environmental science, GITAM Institute of Science, GITAM (Deemed to be) University, Visakhapatnam-45, India

Vara S, Karnena MK 2020 - Fungal enzymatic degradation of industrial effluents - A review. Current Research in Environmental \& Applied Mycology (Journal of Fungal Biology) 10(1), 417442, Doi 10.5943/cream/10/1/33

\begin{abstract}
Environmental and economic affable technology that is mechanized by the enzymes of microbes is bioremediation. Microorganisms like bacteria, fungi and plant life produce large number of digestive enzymes that has been researched and reported regarding their involvement in degrading the persistent pollutants which are lethal to human life. Fungal enzymes possess advantages over additional resources owing to their applicability and sustenance, even in deviant and unfavorable environmental circumstances. Research in exploring these enzymes helped a lot in contributing towards sustainable development of bioprocess technology to reduce the noxiousness of the pollutants. This review is an attempt offering descriptive information on the digestive enzymes from fungi, their application in degrading wide variety of contaminants. Advanced methods like using immobilized fungal cells or enzymes in beads or carriers have received good success and thus future holds promise for development of genes required in cloning for the decolorization and decomposition of dyes as well as bioengineered fungi that can utilize pollutants or various industrial effluents as substrates.
\end{abstract}

Key words - Bioremediation - Enzymes - Enzyme activity - Extracellular enzymes - fungal degradation - Laccases - Lipases and Peroxidases

\section{Introduction}

Toxic pollutant elimination from industrial effluents is practiced over several decades, nevertheless physico-chemical processes like oxidation and reduction evaporation, chemical precipitation, filtration, reverse osmosis, electrochemical treatment and ion-exchange are restricted owing to their cost effectiveness and do not guarantee satisfactory treatment of the effluent. Furthermore, these processes are generally strenuous and pricey, because of the intricacy and volume of effluents released during production process (Crini \& Lichtfouse 2019).

These reasons have necessitated requirement for development of novel and advanced technologies which accentuate the destruction of pollutants otherwise not effective through conventional method of disposal. Previous two decades have witnessed notable rise in search of eco-friendly and cost-effective alternatives for conventional methods of handling wastes. Among the identified technologies which were promising were those which have meticulously mimicked the time-tested natural systems that were successful in restoring environments to their original status upon objectionable distresses. Indeed, the process of self-restoration ability by nature, which is infinite, was in fact responsible for birth to the concept.

These technologies involve utilizing microorganisms like bacteria, yeast, algae and fungi and 
algae for treating industrial effluents, which obtained attention and reputation in the last few decades owing to their enhanced performance and less cost, steady effect and easy retrieval of treasured metals (Rehman \& Shakoori 2001, Wang et al. 2001). Termed as bioremediation this technology is regarded to end up being the most appropriate approach for treating industrial effluents as it provides long lasting remedy for clean-up and also removal of poisonous pollutants via metabolic reactions mediated by organisms (Pearce \& Ollerman 1998).

Deemed to be possessing beneficial enzymes, microorganisms, have great variation between genera in ability of production of specific enzymes, which is dependent on specific medium and $\mathrm{pH}$. During the recent years, utilizing microorganisms for sources of significant industrial enzymes has gained stirred attention for assessment of their enzymatic action. (Saranraj \& Stella 2013, Akpan et al. 1999, Pandey et al. 2000, Abu et al. 2005). Microbial enzymes have remarkable potential for degradation of diversed nature of organic compounds (Alexander 1981). Owing to the following advantages enzymes from microbes are preferred over plants to animal sources:

1. Economic in production

2. More manageable and anticipated enzyme contents

3. Dependable supplies of raw material with stable composition which can be easily arranged

The biology of fungi, their financial worth and pathogenic features are not new to the civilization. Fungi are recognized for their greater abilities of generating vide varieties of proteins, acids and other catabolic products, over all their entire enzymes have made them more soughted out more than microbial enzymes their capability to adapt in serious environmental constrains (Kües 2015, Kadri 2017, Quintella et al. 2019). Fungi have been utilized for varied applications ranging from food fermentation to production of pharmaceuticals. The biodegradation of undesirable components by fungi involve converting them into tolerable, useful or harmless products (Tripathi et al. 2007).

Fungi are regarded as nature's most active agents for decomposition of waste as they secrete a variety of extracellular enzymes, forming an indispensable element in soil-food-web (Rhodes 2012). Among other decompositions of lignocellulose is regarded to be the most crucial process in the carbon cycle of earth (Rhodes 2013). Indeed, these are the solitary organisms which can decompose wood on earth, especially 'white-rot-fungi' are unique, as they require lignin for their growth which acts as a carbon source (Kirk et al. 1976). Table 1 presents the materials that are degraded by fungi.

Table 1 Materials degraded by Fungi (Kirk et al. 1976)

\begin{tabular}{|l|l|l|}
\hline Wood & Plastics & Library Materials \\
\hline Wooden airfacts & Wool & Wall Paintings \\
\hline Stored Paper & Wrapping Papers & Electro insulating materials \\
\hline Textiles & Glass Surfaces & Coal \\
\hline Leather & Concrete & Ground waste rubber materials \\
\hline
\end{tabular}

In order to achieve fruitful mycoremediation (remediation using fungi), selection of correct fungal species for targeting specific pollutant is necessary (Matsubara et al. 2006, Rhodes 2014). Table 2 presents a few important industrial digestive enzymes from fungi (Martin \& Christopher 1990)

Table 2 presents a few important industrial digestive enzymes from fungi (Martin \& Christopher 1990).

\begin{tabular}{|l|l|l|l|l|l|}
\hline Enzyme a & EC number $\underline{\mathbf{b}}$ & Source & $\begin{array}{l}\text { Intra/extra } \\
\text {-cellular } \underline{c}\end{array}$ & $\begin{array}{l}\text { Scale of } \\
\text { production } \underline{\mathbf{d}}\end{array}$ & Industrial use \\
\hline Fungal enzymes & & & & & \\
\hline$\alpha$-Amylase & 3.2 .1 .1 & Aspergillus & E & ++ & Baking \\
\hline
\end{tabular}


Table 2 Continued.

\begin{tabular}{|c|c|c|c|c|c|}
\hline Enzyme a & EC number $\underline{b}$ & Source & $\begin{array}{l}\text { Intra/extra } \\
\text {-cellular c }\end{array}$ & $\begin{array}{l}\text { Scale of } \\
\text { production } \mathbf{d}\end{array}$ & Industrial use \\
\hline Aminoacylase & 3.5 .1 .14 & Aspergillus & $\mathrm{I}$ & - & Pharmaceutical \\
\hline Glucoamylase $^{\mathrm{k}}$ & 3.2.1.3 & Aspergillus & $E$ & +++ & Starch \\
\hline Catalase & 1.11.1.6 & Aspergillus & $\mathrm{I}$ & - & Food \\
\hline Cellulase & 3.2.1.4 & Trichoderma & $E$ & - & Waste \\
\hline Dextranase & 3.2.1.11 & Penicillium & $E$ & - & Food \\
\hline Glucose oxidase & 1.1.3.4 & Aspergillus & I & - & Food \\
\hline Lactase & 3.2 .1 .23 & Aspergillus & $\mathrm{E}$ & - & Dairy \\
\hline Lipase $^{\mathrm{e}}$ & 3.1 .1 .3 & Rhizopus & $\mathrm{E}$ & - & Food \\
\hline Rennet $^{\mathrm{m}}$ & 3.4.23.6 & Mucor miehei & $E$ & ++ & Cheese \\
\hline Pectinase $^{n}$ & 3.2.1.15 & Aspergillus & $\mathrm{E}$ & ++ & Drinks \\
\hline Pectin lyase & 4.2.2.10 & Aspergillus & $E$ & - & Drinks \\
\hline Protease $^{\mathrm{m}}$ & 3.4.23.6 & Aspergillus & $E$ & + & Baking \\
\hline Raffinase $^{\circ}$ & 3.2.1.22 & Mortierella & $\mathrm{I}$ & - & Food \\
\hline
\end{tabular}

a the names in common usage are given. As most industrial enzymes consist of mixtures of enzymes, these names may vary from the recommended names of their principal component. Where appropriate, the recommended names of this principal component are given below

${ }^{\mathrm{b}}$ The EC number of the principal component

${ }^{\mathrm{c}}$ I - intracellular enzyme; E - extracellular enzyme

$\mathrm{d}+++>100$-ton year ${ }^{-1} ;++>10$-ton year ${ }^{-1} ;+>1$-ton year ${ }^{-1} ;-<1$-ton year ${ }^{-1}$

e triacylglycerol lipase

${ }^{\mathrm{f}}$ chymosin

g Endo-1,3(4)- $\beta$-glucanase

${ }^{\mathrm{h}}$ xylose isomerase

${ }^{\mathrm{i}}$ subtilisin

${ }^{\mathrm{j}} \alpha$-dextrin endo-1,6- $\alpha$-glucosidase

${ }^{\mathrm{k}}$ glucan $1,4-\alpha$-glucosidase

${ }^{1} \beta$-galactosidase

${ }^{\mathrm{m}}$ microbial aspartic proteinase

${ }^{\mathrm{n}}$ polygalacturonase

${ }^{\mathrm{o}} \alpha$-galactosidase

${ }^{\mathrm{p}} \beta$-fructofuranosidase

\section{Industrial application of Fungi Enzymes}

\section{a-Amylase}

First enzyme to be produced industrially in 1894, amylase (Crueger \& Crueger 1984) is the enzyme that breaks down starch into sugar. Owing to their intended technological implication and monetary benefits, amylase have received a pronounced attention. $\alpha$ - amylase is used for production of glucose commercially (Hema et al. 2006). Successful applications of microbial amylases include starch saccharification, baking, textile, paper and pulp, brewing and detergent industries along with advanced applications for medical, clinical and analytical chemistry (Saranraj \& Stella 2013).

\section{Aminoacylase}

Utilized for the creation of L-amino acids aminoacylases are involved in industrial settings from late 1950s (Sato \& Tosa 2010, Birnbaum et al. 1952). Fungi belonging to the genus Hypomyces, Fusarium, Auricularia, Pythium, and Menisporopsis are capable of producing Daminoacylase. Microbes release specific enzymes like D or L aminoacylase (Little child 2015) and these compounds help in producing amino acids (Drauz 1997), contains nitrogen acts as an pharmaceutically active compounds. 


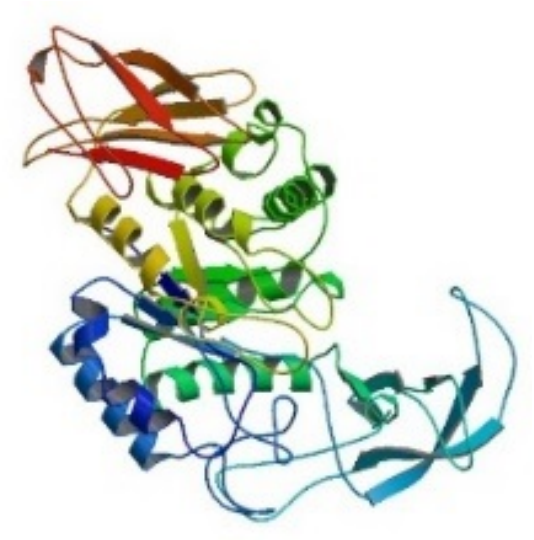

Fig. 1 - Structure of Alpha-Amylase Precursor (Reproduced with permission from Hwang et al. 1997)

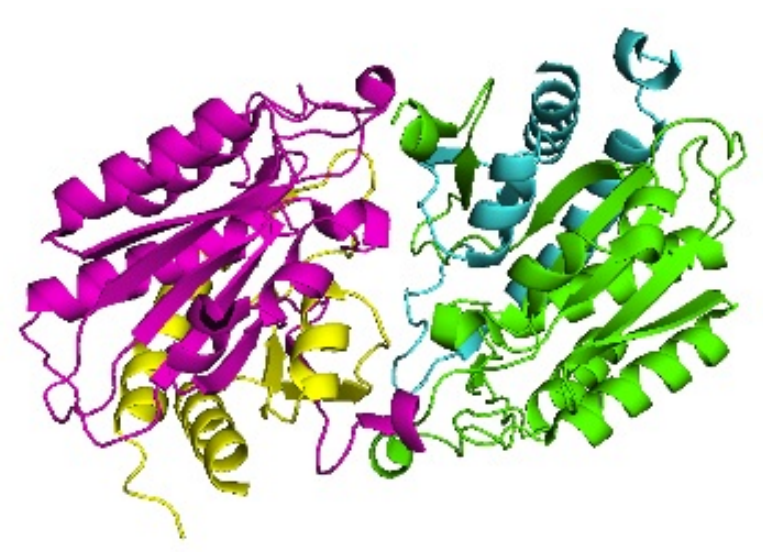

Fig. 2 - Quaternary structure of an Aminoacylase (Reproduced with permission from en.wikipedia.org)

\section{Glucoamylase}

One of the oldest and widely used biocatalyst in food industry is Glucoamylase (GA). Glucose is obtained from non-reducing ends of starch by hydrolysing $\alpha-1,4$ glycosidic bonds and it even has a ability to hydrolyse $\alpha-1,6$ linkages at a inferior level (Mertens \& Skory 2006). Saccharification of partially processed starch/dextrin to glucose is a single of the major program of glucoamylase, which is a necessary substrate for abundant fermentation procedures and range of beverage and meals industries. For industrial purposes glucoseacylase has been traditionally produced from filamentous fungi as they secrete huge quantities of the enzyme extracellularly (Kumar \& Satyanarayana 2009). Among other fungi involved in production of the enzyme important for industrial application involve Rhizopus oryzae, Aspergillus niger and Aspergillus awamori (Coutinho \& Reilly 1997).

\section{Catalase}

Catalase is an ubiquitous enzyme can degrade hydrogen peroxide into oxygen and water generally present in aerobic organisms and acts against deleterious properties of reactive oxygen species like Hydroxyl radicals, Superoxide anions etc. (Susmitha et al. 2013). Two types of largesize subunit catalases (L1 and L2) are present in filamentous ascomycetes. L2-type is extracellular in natures which are usually induced by various stressors; on the other hand, L1-type accumulates in asexual spores and is not inducible (Hansberg et al. 2012). Major applications of catalases include bleaching of cotton fabrics (Alexandra et al. 2002), food industry (Hengge 1999); contact lens hygiene (Cook \& Worsley 1996). 


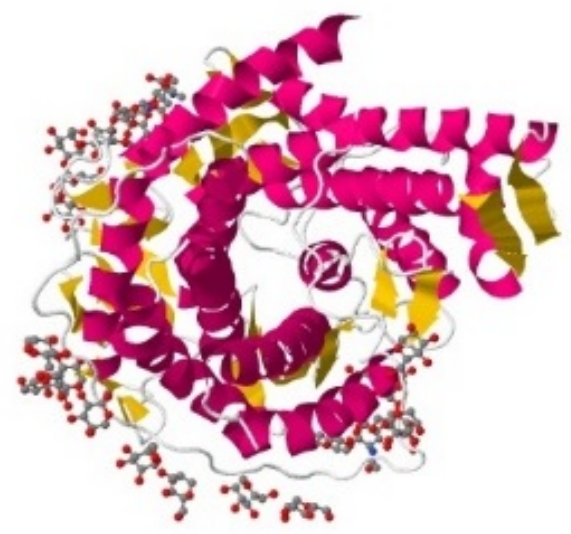

Fig. 3 - Refined crystal structures of Glucoamylase from Aspergillus Awamori Var. X100 (Reproduced with permission from Aleshin et al. 1994)

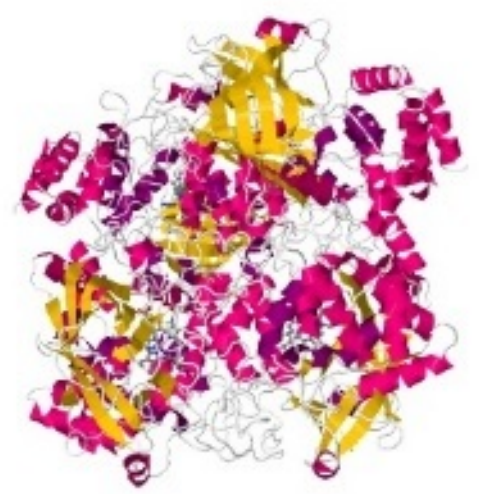

Fig. 4 - Catalase A from Saccharomyces Cerevisiae (Reproduced with permission from Maté et al. 1999)

\section{Cellulase}

Structurally simpler in comparison to cellulase bacterial systems, cellulosomes fungal cellulases (Bayer et al. 1994, 1998) are those that characteristically have two different provinces: a catalytic domain (CD) and a cellulose binding module (CBM), hinged by short poly-linker region to catalytic domain at N-terminal (Carvalho et al. 2003, Bayer et al. 2004). Owing to enzyme complexity system and enormous industrial prospective, cellulases became prospective for exploration by speculative and industrialized groups. Microbial cellulases reported impending application in numerous industries including textile, pulp and paper, laundry, food, brewing, agriculture and biofuel production (Kuhad et al. 2011).

\section{Dextranase}

Endo-dextranase enzyme from glucosyl transferases family, dextranase is produced from certain strain of microorganism. Dextranase can hydrolyze dextran to low-molecular-weight polysaccharides, it favourably cleaves the 1, 6-A- glucosidic linkages in dextran and its degradation products. These have major important applications in medicine (Yu-Qi et al. 2017) and sugarcane processing (Gibriel et al. 2014).

\section{Glucose oxidase}

Gluconic acid is obtained by oxidation of $\beta$-d-glucose and it is catalysed by Glucose oxidase 
(GOX). through employing molecular oxygen for accepting electron along with producing hydrogen peroxide simultaneously. It is considered as safe and its production from A. niger has been basis for several industrial applications. GOX from microbes has been receiving great attention owing to its extensive uses in pharmaceutical, chemical, beverage, food, biotechnology, clinical chemistry and many other industries (Bankar et al. 2009). One of its novel applications comes from its electrochemical activity which makes it a significant constituent in glucose sensors and impending in fuel cell applications that have increased its demand in recent years (Wong et al. 2008).

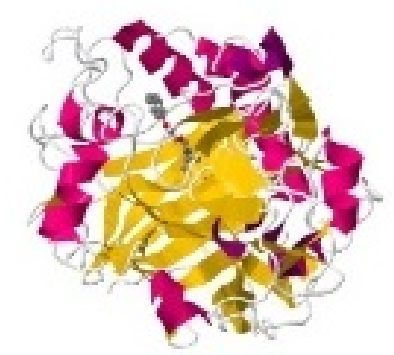

Fig. 5 - Catalytic modules of Cel7D from Phanerochaete chrysosporium as a chiral selector: Structural studies of its complex with the b-blocker (R)-propranolol (Reproduced with permission from Muñoz et al. 2003)

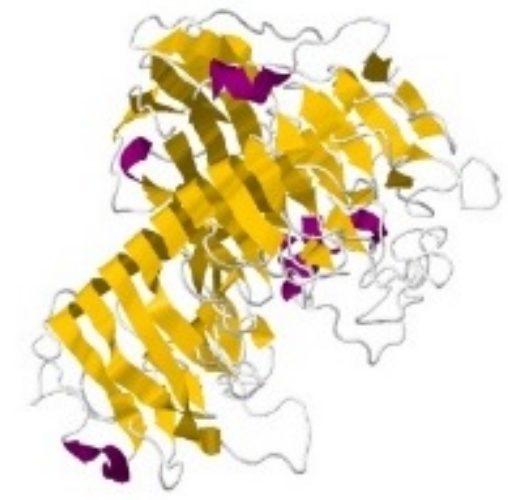

Fig. 6 - Dex49A from Penicillium minioluteum (Reproduced with permission from Larsson et al. 2003)

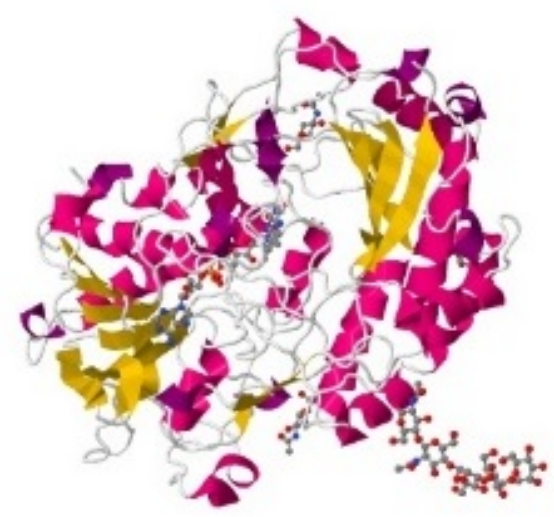

Fig. 7 - Glucose Oxidase from Penicillium Amagasakiense (Reproduced with permission from Wohlfahrt et al. 1999) 


\section{Lactase}

Lactase is an enzyme which brings about break down of milk sugar lactose to glucose and galactose (Borglum \& Sternberg 1972). This have been broadly studied during the recent years (Mehaia \& Cheryan 1987), owing to the technique of enzyme immobilization that has paved new and motivating possibilities for use of this sugar. Lactase applications involve in bread production (Pomeranz \& Miller 1963), thickness decreasing of frozen milk products (Stimpson 1954), enlightening animal fodders (Stimpson 1957) and ice cream containing milk solids will be enhanced (Sampey \& Neubeck 1955). Having safe use history this is being subjected to numerous safety tests lactase obtaining from A. niger, A. oryzae and Kluyveromyces lactis are deliberated to be harmless.

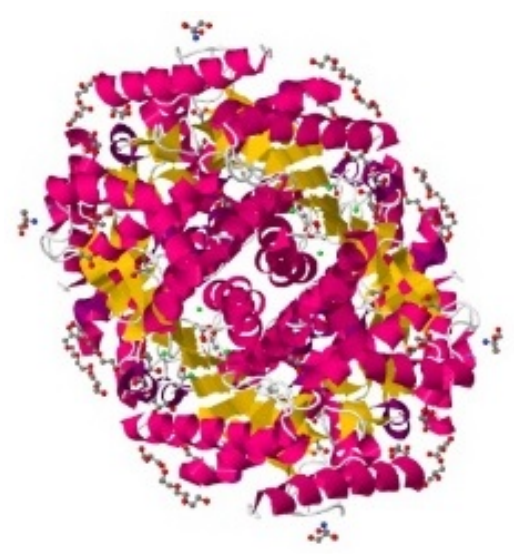

Fig. 8 - Crystal structure of MGS-M5, a lactate dehydrogenase enzyme from a Medee basin deepsea metagenome library (Reproduced with permission from Alcaide et al. 2015)

\section{Lipases}

Lipase belongs to the class of hydrolyses. Fatty acids and glycerol are obtained by catalysing the hydrolysis of triglycerides over an oil-water suspension, which also catalyse hydrolysis and Trans esterification of other esters including the production of esters and also exhibiting enation selective properties. Lipase has a capability to perform precise chemical transformations, stability and Broad spectrum substrate specificity (Dutra et al. 2008, Griebeler et al. 2011; owing to these properties it has enhanced popularity in the applications of detergent, food, cosmetic, organic synthesis, and pharmaceutical industries (Park et al. 2005, Gupta et al. 2007, Grbavčić et al. 2007, Franken et al. 2009). Advanced applications include their activity as biocatalysts in lipid technology that have been used insitu and exsitu complex manufacturing applications (Joseph et al. 2008). Among other microorganisms fungoid types are specifically cultured in solidstate fermentation (SSF) for production of lipases (Abada 2008, Dutra et al. 2008).

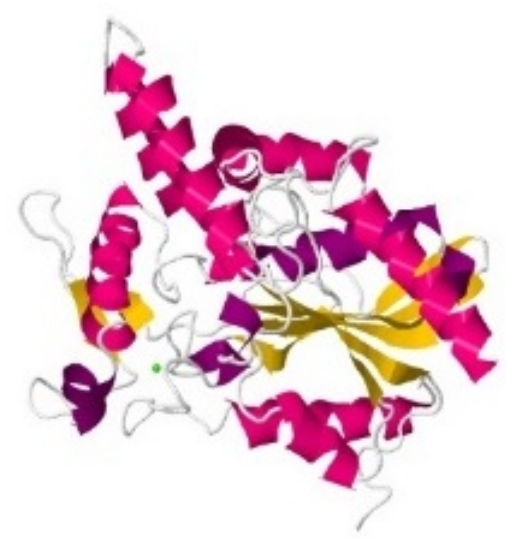

Fig. 9 - Structure of Lipase (Reproduced with permission from Kim et al. 1997) 


\section{Rennet}

Microbial rennets obtained from various microorganisms, which are commercially promoted in the trade names like as Hanilase, Fromase, Rennilase, Marzyme, etc. are being promoted since the 1970s, these which have demonstrated acceptable for manufacture of different kinds of cheese. Apart from various strains of species of Mucor that are frequently used for manufacture of microbial rennets others include Endothia parasitica, Aspergillus oryzae, Irpex lactis, Rhizomucor pusillus and $R$. miehei. Presently microbial rennet is used in nearly $1 / 3^{\text {rd }}$ of the cheese manufactured worldwide.

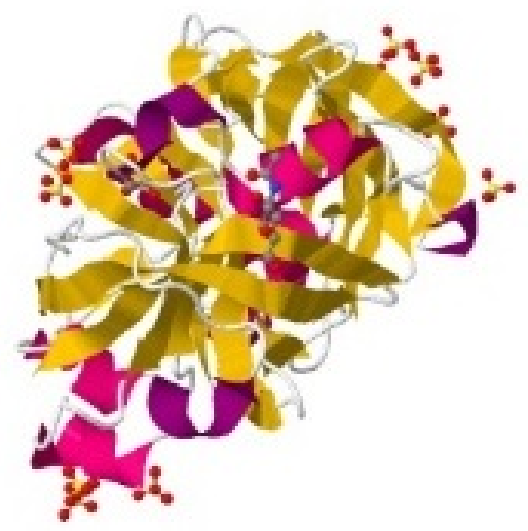

Fig. 10 - Camel chymosin at 1.6A resolution (Reproduced with permission from Langholm Jensen et al. 2013)

\section{Pectinase}

Pectinase present in the cell walls of plants. Pectinase is a polysaccharide substrate, which splits the pectin into of polygalacturonic acid into monogalacturonic acid by linking of glycosidic linkages. Peels of the fruits which are made of pectin layer can be easily assimilated by microbial pectinases in order to extract juices from the fruits. Hence, pectinase enzymes are generally used in processes that involve break down of plant materials, like speeding up the extraction of fruit juice. Currently nearly all the pectinolytic enzymes utilized for industrial purposes are produced by fungi comprising of Rhizopus stolonifer, Fusarium oxysporum, Aspergillus sp., Alternaria mali, Penicillium italicum, Neurospora crassa and many others. Orange peels are used as substrate for the growth of Aspergillus niger (Beulah et al. 2015, Abe et al. 1988, Aguilar \& Huitron 1987).

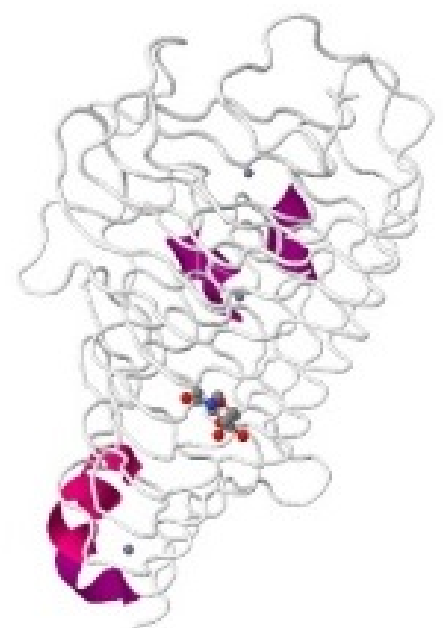

Fig. 11 - Endo-Polygalacturonase II from Aspergillus niger (Reproduced with permission from van Santen et al. 1999) 


\section{Pectin lyase}

Middle lamella of higher plants and cell walls, contain pectin lyase enzyme which acts upon peptic materials and immensely leading for technological innovations and also helps in the productivity and reduce economic costs. About 25\% of the world's enzyme production is solely from this enzyme (Alkorta et al. 1998, Kashyap et al. 2001). This enzyme is proved to be very important in applications for industries like food, paper and textile (Yadav et al. 2009). Pectic enzymes that are utilized in food industry, for commercial purpose have a mixture of oxidoreductase, hemicellulose, proteases, cellulases and glycosidases (Krop \& Pilnik 1974, Mc Feeters 1985).

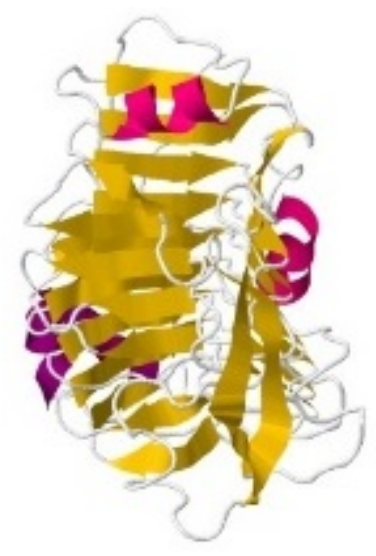

Fig. 12 - Pectin Lyase A (Reproduced with permission from Mayans et al. 1997)

\section{Protease}

These are assembly of enzymes, whose catalytic purpose is to hydrolyze peptide bonds of proteins and break down them into polypeptides or free amino acids (Deng et al. 2010). They are associated in a many physiological reactions ranging from basic digestion of food proteins to highly controlled cascades (Hooper 2002, Oseni 2011).

Industrial application of these enzymes includes photographic industries, food, leather, tanning, pharmaceutical, detergents industries and waste treatment (Jellouli et al. 2009, Bhaskar et al. 2007, Gupta et al. 2002). These are divided into 3 groups, acid, neutral and alkaline proteases based on their acid-base behavior. Acid proteases are those that perform finest at $\mathrm{pH}$ range of 2.05.0, these are typically produced by fungi. Favoured source of enzyme is microorganisms as these are rapid in growth, entail partial space for cultivation and also has ease for heritable manipulation in order achieve novel enzymes with changed properties desirable for numerous applications (Kocher \& Mishra 2009).

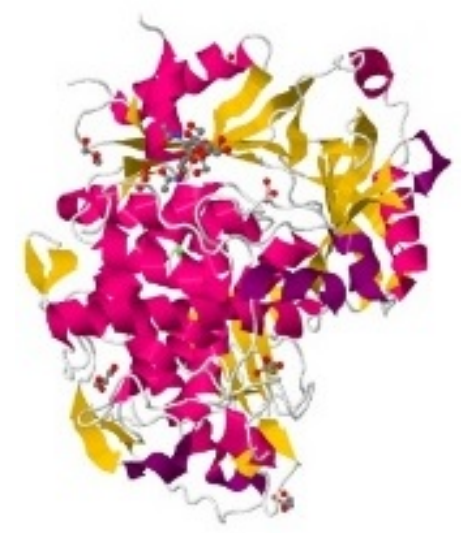

Fig. 13 - Extracellular metalloproteinases from Aspergillus (Reproduced with permission from Fernández et al. 2013) 


\section{Raffinase}

An enzyme that hydrolyzes raffinose, yielding fructose in the reaction is raffinase. Nearly $40 \%$ of totally obtainable enzymes such as raffinase, amylases, dextranase, lactase, pectinase and cellulose are from filamentous fungi especially Aspergillus spp. (Archer \& Peberdy 1997). Industrial applications include food (Singh \& Kayastha 2013).

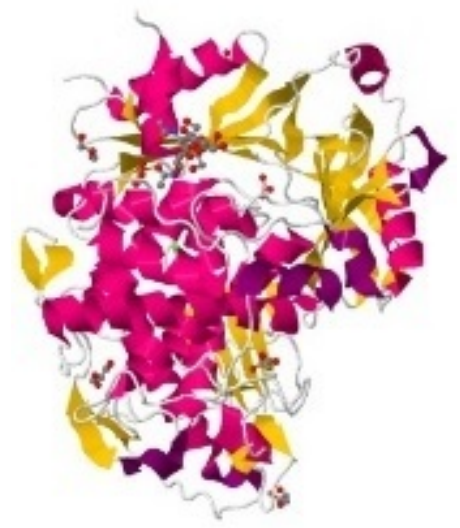

Fig. 14 - Crystal structure of alpha-galactosidase I from Mortierella vinacea (Reproduced with permission from Fujimoto et al. 2009)

\section{Application of Fungal Enzymes for treating industrial effluents}

Capable of producing rare enzymes proficient in performing under chemically difficult conditions fungi are efficient in exploiting minimal living conditions at large (Viswanath et al. 2008, Shraddha et al. 2011). Possessing characteristics of high selectivity and efficiency along with environmentally benevolent reactions, enzymes have achieved significant attention for removal of environmental and industrial pollutants. Among such enzymes that were studied, fungal extracellular enzymes of two major classes i.e., peroxidases (lignin and manganese) and laccases have been extremely exploited for studies of pollutant removal including toxic phenolic compounds and recalcitrant xenobiotics. Innumerable studies have been reported during the recent years focussing on improvement of fabrication of these enzymes, screening of novel fungal strains, amendments in evolution conditions, utilizing inducers and search for economically viable growth substrates like food and agricultural wastes (Viswanath et al. 2014). Bioremediation of industrial effluents via enzymatic approach involves conversion of toxic and complex chemical substances into safe compounds through removal of few functional groups either in-vivo or in-vitro processes (Venkatesagowda et al. 2012, Messias et al. 2009, Balaji et al. 2014). The following discussion provides an insight into fungal enzymes utilized for treatment of industrial effluents. Table 3 provides an overview of various pollutants in industrial effluents degraded by respective fungal enzymes.

Table 3 Fungal enzymes employed for degradation of various pollutants in industrial effluents

\begin{tabular}{|l|l|l|l|}
\hline \multicolumn{1}{|c|}{ Fungus } & \multicolumn{1}{c|}{ Enzyme } & \multicolumn{1}{c|}{ Industrial Pollutant } & \multicolumn{1}{c|}{ References } \\
\hline Caldariomyces fumago & Chloro peroxidase & Phenols & Wannstedt et al. 1990 \\
\hline Coprinus cinereus & Peroxidease & Phenols & Budde et al. 2001 \\
\hline C.cinereus & Peroxidase and $\mathrm{H}_{2} \mathrm{O}_{2}$ & Phenols & Kauffmann et al. 1999 \\
\hline Pleurotus eryngii & Versatile peroxidase & Phenols and Hydroquinones & Gómez-Toribio et al. 2001 \\
\hline P.eryngii & Versatile peroxidase & 2,4-DCP & Rodriguez et al. 2004 \\
\hline Bjerkanderaadusta & Versatile peroxidase & PCP & Davila-Vazquez et al. 2005 \\
\hline P.eryngii & Versatile peroxidase & $\begin{array}{l}\text { Benzyl, Cinnamyl,napthyl, } \\
\text { andaliphatic, unsaturated } \\
\text { alcohols }\end{array}$ & Guillen et al. 1992 \\
\hline
\end{tabular}


Table 3 Continued.

\begin{tabular}{|c|c|c|c|}
\hline Fungus & Enzyme & Industrial Pollutant & References \\
\hline $\begin{array}{l}\text { Penicillium } \\
\text { simplicissimum }\end{array}$ & Aryl-alcoholoxidase & Vanilly alcohol & De Jong et al. 1992 \\
\hline $\begin{array}{l}\text { Penicillium } \\
\text { simplicissimum }\end{array}$ & Methyl transferase & $\begin{array}{l}\text { Phenols, benzoic acids, -OH } \\
\text { substituents, etc. }\end{array}$ & Jeffers et al. 1997 \\
\hline Aspergillus nidulans & $\begin{array}{l}\text { N-Acetyl-6-hydroxy } \\
\text { tryptophan oxidase }\end{array}$ & Cersol & Birse \& Clutterbuck 1990 \\
\hline Chrysonilia sitophila & LiP type III & Bleach Plant & Dezotti et al. 1995 \\
\hline Chrysonilia sitophila & Free LiP, LiP III & Bleach Plant & Ferrer et al. 1991 \\
\hline $\begin{array}{l}\text { Phanerochaete } \\
\text { chrysosporium }\end{array}$ & $\mathrm{MnP}$ & Bleach Plant & Michel et al. 1991 \\
\hline Coriolus versicolor & Laccase & Bleach Plant & Davis \& Burns 1990 \\
\hline \multicolumn{4}{|l|}{ Laccase } \\
\hline C.versicolor & Laccase & 2,4,6-ТCP,0.5-5mM & Ullah et al. 2000 \\
\hline T.versicolor & Guaiacol & 2,4,5-TCP, 2mM & Roper et al. 1995 \\
\hline Pleurotus ostreatus & Laccase & 2,6- Dimethoxyphenol, 1mM & Hublik \& Schinner 2000 \\
\hline panus tigrinus & $\mathrm{MnP}$ & 2,4,6-ТСР,0.5-5mM & Leontievsky et al. 2000 \\
\hline T.versicolor & Laccase & Anthracene, 15mg/l & Johannes et al. 1996 \\
\hline Pycnosporus cinnabrinus & Laccase & $\begin{array}{l}\text { Benzo }[\alpha] \text { pyrene } 1,6-3,6 \text { and } \\
6,12 \text {-quinones }\end{array}$ & Rama et al. 1998 \\
\hline Coriolopsis gallica & Laccase & Anthracene. $20 \mu \mathrm{M}$ & Pickard et al. 1999 \\
\hline Trametes versicolor & Laccase & Delignification & Paice et al. 1996 \\
\hline Pycnosporus cinnabrinus & Laccase & Delignification & Balakshin et al. 2001 \\
\hline Trametes villosa & Laccase & Delignification & $\begin{array}{l}\text { Chakara \& Ragauskas } \\
2001\end{array}$ \\
\hline Coriolus versicolor & Laccase & Delignification & Balakshin et al. 2001 \\
\hline \multicolumn{4}{|l|}{ Peroxidase } \\
\hline P.chrysosporium & $\mathrm{LiP}$ & BenBenzo $[\alpha]$ pyrene & Haemmerli et al. 1986 \\
\hline $\begin{array}{l}\text { Phanerochaete } \\
\text { chrysosporium }\end{array}$ & $\mathrm{MnP}$ & 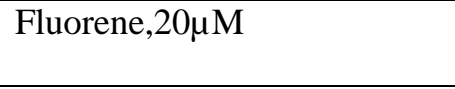 & Bogan et al. 1996 \\
\hline Nematoloma frowardii & $\mathrm{MnP}$ & $\begin{array}{l}\text { Anthracene, Pyrene, } \\
\text { Fluoranthene }\end{array}$ & Ute \& Fritsche 1997 \\
\hline Trametes versicolor & $\mathrm{MnP}$ & Phenethrene & Collins \& Dobson 1996 \\
\hline $\begin{array}{l}\text { Phanerochaete } \\
\text { chrysosporium }\end{array}$ & Peroxidase & Methylated Lignin & Tien \& Kirk 1983 \\
\hline Nematoloma frowardii & Peroxidase & Milled Straw & Hofrichter et al. 1999 \\
\hline Nematoloma frowardii & Peroxidase & DHP & Steffen et al. 2000 \\
\hline S.coronilla & Peroxidase & Non-Phenolic lignin & Kapich et al. 2005 \\
\hline P. chrysosporium & Crude LiP & $\begin{array}{l}\text { Azure B, Tropaeolino, } \\
\text { Orange2 }\end{array}$ & Cripps et al. 1990 \\
\hline Bzerkanderaadusta & $\mathrm{MnP}$ & Reactive Blue15 & $\begin{array}{l}\text { Heinfling-Weidtmann et al. } \\
2001\end{array}$ \\
\hline Bjerkanderaadusta sp. & $\mathrm{MnP}$ & Orange2 & Lopez et al. 2002 \\
\hline P. chrysosporium & $\mathrm{MnP}$ & Crystal Violet polyR:478 & Moldes et al. 2003 \\
\hline White:Rot Fungus & $\mathrm{LiP}$ & $\begin{array}{l}\text { AcidBlue 25, Indigo } \\
\text { Carmine, Reactive Blue }\end{array}$ & Young \& Yu 1997 \\
\hline
\end{tabular}

\section{Lipases}

Triacylglycerol acylhydrolases catalysing hydrolysis of triacylglycerol to fatty acids and glycerol are called Lipases (Thakur 2012). Apart from hydrolysis of triglycerides, lipases catalyze diversity of chemical reactions including esterification, acidolysis, trans-esterification and aminolysis. Infact lipase is often used for catalysing hydrolysis of varied substrates which are not natural to obtain selective enantio- and regio substrates (Wang et al. 2015, Facchini et al. 2016). 
Fungal species having capability to secrete lipases that deteriorate fats and oils are found in soils polluted with discharge from the products of oil and dairy (Niyonzima \& More 2014).

Lipases have been explored extensively for treating waste water (Dauber \& Boehnke 1993). Deterioration of polyvinyl alcohol films and bioremediation of polluted soils was possible by lipase from Aspergillus niger and Aspergillus terreus respectively (Jecu et al. 2010, Mahmoud et al. 2015). Lipase from other species that have shown effective bioremediation are Aspergillus ibericus and Aspergillus uvarum (Salgado et al. 2016). Essentially lipolytic enzyme from Aspergillus niger that have been isolated from soil polluted by oil have reported to degrade polyaromatic hydrocarbons (Mauti et al. 2016, Margesin et al. 1999, Riffaldi et al. 2006, Prasad \& Manjunath 2011).

Mechanism of Lipase Activity - Reactions of lipolytic activity occur at the interface of lipidwater, resulting in formation of balance among monomeric, emulsified, and micellar states by lipolytic substrates (Sharma et al. 2011). Triglyceride being the chief constituent of fat or natural oil hydrolyzes successively to monoacylglycerol, fatty acids, glycerol and diacylglycerol among which glycerol and fatty acids are extensively utilized as raw materials. Ex: monoacylglycerol utilized in pharmaceutical cosmetic and food industries as emulsifying agent. A report on hydrolysis of triolein produced from Candida rugose lipase in oil-water biphasic system has proved to be efficient. Lipase adsorbs first on oil-water interface of the bulk water phase and then breaks triolein ester bonds resulting in production of monoolein, diolein and glycerol consecutively. Oleic acid is released at each successive reaction stage in the process of catalysis. Since glycerol released is in hydrophilic nature it gets dissolved in aqueous phase (Hermansyah et al. 2007).

\section{Laccases}

Belonging to minor group of enzymes, laccases are named - the blue copper proteins or the blue copper oxidases (Xu 1996, Thurston 1994) among others. These are oxidoreductases that oxidize diphenols along with other associated substances using molecular oxygen as electron acceptor (Viswanath et al. 2008, Thurston 1994). Their utilization as biocatalysts for organic synthesis has been ignored previously, perhaps as they were unavailable commercially (Riva 2006, Baldrian 2006, Joo et al. 2008).

Laccases are predominantly abundant in numerous white-rot fungi engaged in metabolism of lignin (Bourbonnais et al. 1995). Fungal laccases degrade lignin and remove potentially toxic phenols produce during the degradation of lignin (Thurston 1994). Additionally, fungal laccases are assumed engage in the release of dihydroxynaphthalene melanins, which are darkly pigmented polymers produced by organisms opposed to environmental stress (Henson et al. 1999) and morphogenesis of fungi by catalysing development of extracellular pigments (Zhao \& Kwan 1999). With reference to their use in biotechnology, fungal laccases gained extensive applications, extending from effluent decolouration and pulp bleaching detoxification, organic synthesis, elimination of phenolics in wines, biosensors, obstructing functions of dye transfer in washing powders and detergents and synthesis of composite medical compounds, numerous of which have been patented (Yaver et al. 2001). Enhancement in biotechnological utilization of laccase was possible with induction of laccase-mediators that are proficient to oxidise non-phenolic compounds, which are or else scarcely or not oxidised by only enzyme (Couto \& Herrera, 2007, Mendonça et al. 2008).

Mechanism of Laccase Activity - Laccased catalysed reactions continue by monoelectronic oxidation of suitable substrate molecule into equivalent reactive radical (Riva 2006). Process of redox reaction is possible with support of group of copper ions which form catalytic central of the enzyme (Wong et al. 2008). Of specific interest are laccases with respect to impending applications, owing to their competences of oxidizing extensive range of environmentally dangerous substrates.

Hazardous compounds recognised to have carcinogenic effect owing to their persistence in nature are pentachlorophenols (PCP), polycyclic aromatic hydrocarbons (PAH), 1,1,1-trichloro-2,2bis (4-chlorophenyl)ethane (DDT), polychlorinated biphenyls (PCB), ethylbenzene, benzene, xylene, toluene and trinitrotoluene (TNT). These substances are transformed by fungi through 
bioremediation (Riva 2006). Laccase from ectomycorrhizal fungus Xerocomus chrysenteron responds to DDT pressure in various ways, signifying huge prospective for biodegradation or mineralization of DDT (Chao et al. 2008). Biodegradation of 2, 4-dichlorophenol using surface response methodology by laccase from Pleurotus sp. is one among latest applications established by Bhattacharya \& Banerjee (2008). BPA oxidation using laccase weakens binding of environmental estrogen to ER-alpha resulting in losing all its ER-alpha-dependent impact on cells of cancer propagation Bolli et al. (2008).

Aqueous solutions contaminated by BPA were bioremediated using laccase from Trametes versicolor which is immobilized on hydrophobic membranes in non-isothermal bioreactors (Ricupito et al. 2009).

Xenobiotic compounds that are oxidized by laccases include polycyclic aromatic hydrocarbons (Tekere et al. 2007, Pozdnyakova et al. 2004, Koschorreck et al. 2008), pesticides (Gorbatova et al. 2006, Torres et al. 2003, Ford et al. 2007), and chlorinated phenolics (Colao et al. 2006, Bollag et al. 2003). Furthermore, polycyclic aromatic hydrocarbons, arising from oil deposits were also seen to be degraded by laccases (Hu et al. 2007, Pointing 2001, Galli et al. 2008).

The underlying phenomenon of removal of xenobiotics encompasses pollutant enzymatic oxidation to free quinones or radicals, which experience polymerization and fractional precipitation (Dec \& Bollag 2000). Laccase from white-rot fungus, Trametes hirsuta, was utilized to oxidize alkenes (Niku-Paavola \& Viikari 2000). The oxidation is result of a double-stage process where in enzyme catalyses primary substrate oxidation first, when a mediator is inserted to reaction, it oxidizes secondary substrate, alkene, to the equivalent ketone or aldehyde. Furthermore, laccase is also successful in immobilizing pollutants of soil by combining to humic substances of soil by process which is homologous to synthesis of humic acid in soils (Bollag \& Myers 1992). Other xenobiotics which can be immobilized in similar way include phenolic compounds and anilines such as 3,4-dichloroaniline, 2,4,6-trinitrotoluene or chlorinated phenols (Ahn et al. 2002). The immobilization results in lowering biological accessibility of the xenobiotics and hence reducing their toxicity.

Lacaases also find importance in decolorization of dyes. Owing to their chemical structure, dyes are resistant to waning upon exposure to light, water and other chemicals, hence maximum of them are problematic to decolourize owing to their synthetic origin (Poots et al. 1976). Apart from decolorization these are also utilized for bleaching textiles and also for synthesizing dyes (Setti et al. 1999). Lacasses from Pycnoporus sanguineus have partially decolorized two azo dyes along with wide-ranging decolorization of 2 triphenylmethane dyes (bromophenol blue and malachite green) (Pointing \& Vrijmoed 2000). While, laccase from Trametes hirsute are able to degrade dyes like triarylmethane, indigoid, azo and anthraquinonic dyes that are utilized in dyeing textiles along with 23 industrial dyes (Couto SR, Herrera et al. 1999).

Laccases are indespensible in treating bleach kraft pulp effluetns or detoxification of agricultural derivatives comprising coffee pulp or olive mill wastes (D’Annibale et al. 2000). Isolated from the fungus Flavodon flavus, laccase has shown decolourization of wastewater from kraft paper mill bleach plant (Raghukumar 2000). Similarly purified laccase from white-rot basidiomycete, $T$. villosa degraded bisphenol A, an endocrine-disrupting chemical (Setti et al. 1999). Nonylphenols resulting from partial biodegradation of nonylphenol polyethoxylates (NPEOs) are released into the environment, chiefly because of their incomplete elimination in effluent treatment units (Ying et al. 2002). These are resistant to biodegradation over their parental compounds resulting of being piled up in rivers around world leading to bioacculumation and biomagnification (Heemken et al. 2001, Junghanns et al. 2005). Aquatic hyphomycete Clavariopsis aquatic that secretes laccases has demonstrated to degrade xenoestrogen nonylphenol.

\section{Peroxidases}

Understood to be omnipresent enzymes, peroxidases catalyze lignin oxidation along with other phenolic substances at the cost of hydrogen peroxide $\left(\mathrm{H}_{2} \mathrm{O}_{2}\right)$ in the existence of a mediator. These can be either haem or nonhaem proteins (Kim et al. 2002, Xu 1996). The most studied 
peroxidases owing to their great prospect to degrade toxic substances are lignin peroxidase (LiP), manganese-dependant peroxidase (MnP), and versatile peroxidase (VP). Use of enzymes certainly have potential advantages which includes allowing degradation process under trivial biological conditions, applicability at both high and low contaminant concentrations over an extensive range of temperature, $\mathrm{pH}$ and salinity; suitability to unamenability to loading effects; biorefractory compounds; no acclimatization of biomass and decrease in sludge volume over all ease of regulating process (Nicell et al. 1993).

Fungal heme protein lignin peroxidase (LiP) produces radical cations by oxidizing dimethylated aromatic compounds. These are produced by most white-rot fungi, like Phanerochaete flavido-alba (Ben Hamman et al. 1999), Bjerkandera sp. strain BOS55 (ten Have et al. 1998), Trametes trogii (Vares \& Hatakka 1997), Phlebia ochraceofulva (Vares et al. 1993), and Phlebia tremellosa (Vares et al. 1992). In fact numerous forms of isozymes were identified in $P$. chrysosporium cultures and also in great number of other white-rot fungi (e.g., Trametes versicolor, Bjerkandera adusta, Phlebia radiata). The activity and quantity of LiP isozymes produced by $P$. chrysosporium vary from 2 to 15, which are dependent on the strain, medium composition, method of cultivation and age of the culture.

Also, a glycosylated heme-containing extracellular peroxidase Manganese Peroxide has similar catalytic cycle as that of LiP and horseradish peroxidase (HRP), but uses absolute Mn (II) as a substrate which is widespread in lignocellulose and soil. Secreted in numerous forms in microenvironments by white-rot fungi and some soil litter-decomposing fungi manganese peroxidase is produced by around 56 fungi in liquid and/or solid-state fermentation as compiled by Hofrichter (2002). Distinct group of Basidiomycetes, like families Coriolaceae, Meruliaceae, Polyporaceae, and the soil litter families Strophariaceae and Tricholomataceae secrete MnP. Nearly 11 isozymes of $\mathrm{MnP}$ are reported to be formed by Ceriporiopsis subvermispora (Urzua et al. 1995, Lobos et al. 1994). Five isozymes in P. chrysosporium MP-1 have been detected (Kirk \& Cullen 1998). For both LiP and MnP nitrogen-deficient conditions favour their production.

Both LiP and MnP has been extensively explored for their capabilities of treating various industrial effluents containing complex and varied composition of organic and toxic substances.

Mechanism of Peroxidases Activity - Steadiness of recombinant and innate peroxidases by Phanerochaete chrysosporium were investigated and found that one-electron oxidation by the enzymes will result in production of cation radicals of the contaminants. An impulsive chemical reaction like C-C cleavage of hydroxylation of cation radical's results in the formation of additional hydrophilic products. Metabolism of these products and cometabolism in the existence of appropriate carbon source will lead to the formation of $\mathrm{CO}_{2}$ by these fungi. The mechanism of action of these enzymes result from complex process of oxidation, reduction, methylation, and hydroxylation (Nie et al. 1999).

Both LiP and MnP extracellular peroxidases are capable of cleaving several PAHs in vitro. These vary from each other in the variety of reducing substrates. Great yield in PAH quinones was improved when incubated with extracellular enzymes of white-rot fungi containing great levels of MnP (Field et al. 1992). It has been recognised that one-electron oxidations of several PAHs by Mn (III) suggests the role of $\mathrm{MnP}$ of P. chrysosporium in the breakdown of PAHs in vivo. Lignin peroxidase ( $\mathrm{LiP}$ ) and manganese peroxidase (MnP) produced by Phanerochaete chrysosporium contribute to decolourization of Olive Mill Wastes (Sayadi \& Ellouz 1995). Aromatic rings are cleaved by these enzymes leading to prospective colour removal from dyes. Dyes like Azure B, Tropaeolin O, and Orange II were partially decolorized within 20 minutes by crude LiP in nitrogenlimited cultures of $P$. chrysosporium (Cripps et al. 1990). It was also reported that dye decolorization enhanced with higher LiP concentrations (Wu et al. 1996). Addition of Veratryl alchol (VA) enahces the degradation and decolorization rates of dyes as reported by Ollikka et al. 1993 where in addition of VA improved the decolorization of Reactive Red from 22 to 96\% within a duration of 3 minutes. Different sources of LiP have also shown similar efficiency as reported by Christian et al. 2005 where LiP from Trametes versicolor decolorized Remazol Brilliant Blue R 
(RBBR) in the presence or absence of VA (Ferreira et al. 2000). LiP from P. chrysosporium oxidizes sulfonated azo dyes, generating sulfophenyl hydroperoxides (Chivukula et al. 1995).

Another major area of application of LiP and MnP is in degradation of lignin, which has attracted their use in degradation of paper and pulp mill effluents. White-rot fungi are naturally principal lignin degraders owing to presence of precise genes for the enzymes ( $\mathrm{LiP}$ and MnP) essential for depolymerisation of lignin, other enzymes including laccase and hydrogen peroxidegenerating enzymes and reactive oxygen species (ROSs).

Production of these enzymes can be in diverse combinations, signifying multiple strategies for biodegradation of lignin. In course of lignin degradation oxidation of phenolic compounds to phenoxy radicals happens through lignin-degrading enzymes, whereas oxidation of nonphenolic compounds through cation radicals. Depending on the trend of enzyme production, Hatakka (1994) categorised white-rot fungi into 3 major classes:

(1) The lignin-manganese peroxidase group (LiP-MnP) (e.g., Phlebia radiata and Phanerochaete chrysosporium),

(2) The manganese peroxidase-laccase group (e.g., Rigidoporus lignosus and Dichomitus squalens), and

(3) The lignin peroxidase-laccase group (e.g., Junghuhnia separabilima and Phlebia ochraceofulva).

Diversity of oxidases like glucose-1-oxidase, glucose-2-oxidase or pyranose-2-oxidase, glyoxal oxidase, methanol oxidase, veratryl alcohol oxidase are produced by white-rot fungi in addition to LiPs, MnPs, and laccases, which are sources of $\mathrm{H}_{2} \mathrm{O}_{2}$ used by peroxidases in lignin degradation. It is reported that Glucose-1-oxidase and glucose-2-oxidase play an significant role in the ligninolytic system of $P$. chrysosporium by producing $\mathrm{H}_{2} \mathrm{O}_{2}$. Cellobiose dehydrogenase (CDH), widely produced by both white-rot and brown-rot Basidiomycetes in the family of Coniophoraceae, and some soft-rot fungi and molds have been listed by Henriksson et al. (2000). This enzyme is an extracellular flavin- and heme-containing which can reduce $\mathrm{O}_{2}$ and produce $\mathrm{H}_{2} \mathrm{O}_{2}$.

Other agents aiding in lignin degradation are identified as reactive oxygen species (ROSs), which are required owing to quite big lignocellulolytic enzymes which are difficult in penetrating lignified wood cell walls, hence employing these low-molecular-weight agents towards decay initiation. Being diffusible and small enough in penetrating and aiding in the function of depolymerisation of wood cell walls as hypothesized during the mid of the twentieth century. Though maximum work is reported on hydroxyl radicals $(\cdot \mathrm{OH})$, other ROSs, like peroxyl radicals (ROO - ) and hydroperoxyl radicals ( $\cdot \mathrm{OOH})$ may also be engaged in fungal attack. Yet supplementary biological ROS agents contain singlet oxygen, hypochlorous acid, and peroxynitrite.

\section{Miscellaneous Enzymes}

Produced both by brown - and white-rot fungi oxalate acts as organic acid chelator. Produced at same time as $\mathrm{MnP}$ through liquid cultures of Phanerochaete chrysosporium, $\mathrm{LiP}$ and $\mathrm{MnP}$ can decompose oxalate in the occurrence of VA or Mn (II), respectively. Electron transfer is the meachnism involved in reaction among enzymatically formed $\mathrm{VA}+\bullet$ and oxalate, decarboxylating oxalate and reducing VA+• back to VA. Coexistence of oxalate with lignin-degrading enzyme systems indicates inhibition of lignin degradation as small amount of oxalate is observed to decrease lignin content significantly in bio bleaching experiments (Vares et al. 1992).

\section{Conclusion}

Utilization of fungi for industrial wastewater treatment is an older process which is not a new technology. Though fungi are efficient in treating many wastewaters, nevertheless it is to be understood that still there are numerous sorts of wastewaters which are not degraded by fungi attributed either to slow growth of fungi or trouble in using them for bioreactors. While as new manufacturing products are used, newer varieties of effluents will be generated which may be amenable to degradation by fungi. During contemporary years, action mechanism of white-rot 
fungi associated to organic pollutants was understood to offer great potential for utilization of treating industrial effluents like paper and pulp, textiles, dyes and PCB degradation.

Advanced methods like using immobilized fungal cells or enzymes in beads or carriers have received good success, resulting in reduction of treatment cost. Past decades have witnessed considerable work focussing on screening of fungi and their genes for degradation of various wastes but failed in isolating needs that need specific objectives. Hence, research in this area has opened new prospects for a variety of molecular biology studies related to biodegradation. Future holds promise for development of genes required in cloning for the decolorization and decomposition of dyes as well as bioengineered fungi that can utilize pollutants or various industrial effluents as substrates. Protein engineering is also being considered to enhance catalytic properties of enzymes that will lead to a new generation of tailor-made enzymes to meet specific demands.

\section{Conflict of Interest:}

All the authors declare no conflict of interest.

\section{Acknowledgements}

All the authors are thankful to GITAM (Deemed to be) University, Visakhapatnam, for providing access to E-library, which helps to carry out the study.

\section{References}

Abada EAEM. 2008 - Production and characterization of a mesophilic lipase isolated from Bacillus stearothermophilus AB-1. Pakistan Journal of Biological Sciences, 11(8), 1100-1106.

Abe JI, Bergmann FW, Obata K, Hizukuri S. 1988 - Production of the raw-starch digesting amylase of Aspergillus sp. K-27. Applied Microbiology and Biotechnology 27(5-6): 447450.

Abu EA, Ado SA, James DB. 2005 - Raw starch degrading amylase production by mixed culture of Aspergillus niger and Saccharomyces cerevisae grown on sorghum pomace. African journal of Biotechnology 4(8): 785-790.

Aguilar G, Huitron C. 1987 - Stimulation of the production of extracellular pectinolytic activities of Aspergillus sp. by galacturonic acid and glucose addition. Enzyme and Microbial Technology 9(11): 690-696.

Ahn MY, Dec J, Kim JE, Bollag JM. 2002 - Treatment of 2, 4-dichlorophenol polluted soil with free and immobilized laccase. Journal of Environmental Quality 31(5): 1509-1515.

Akpan I, Bankole MO, Adesemowo AM, Latunde-Dada GO. 1999 - Production of amylase by A. niger in a cheap solid medium using rice bran and agricultural materials. Tropical science. 39: 77-79

Alcaide M, Stogios PJ, Lafraya Á, Tchigvintsev A et al. 2015 - "Pressure adaptation is linked to thermal adaptation in salt-saturated marine habitats". Environ. Microbiol 17(2): 332-345.

Aleshin AE, Hoffman C, Firsov LM, Honzatko RB 1994 - Refined crystal structures of glucoamylase from Aspergillus awamori var. X100. Journal of molecular biology 238(4): 575-591.

Alexander M. 1981 - Biodegradation of chemicals of environmental concern. Science 211(4478): 132-138.

Alkorta I, Garbisu C, Llama MJ, Serra JL. 1998 - Industrial applications of pectic enzymes: a review. Process Biochemistry 33(1): 21-28.

Archer DB, Peberdy JF. 1997 - The molecular biology of secreted enzyme production by fungi. Critical reviews in biotechnology 17(4): 273-306.

Balaji V, Arulazhagan P, Ebenezer P. 2014 - Enzymatic bioremediation of polyaromatic hydrocarbons by fungal consortia enriched from petroleum contaminated soil and oil seeds. Journal of Environmental Biology. 35(3): 521-529. 
Balakshin M, Chen CL, Gratzl JS, Kirkman AG, Jakob H. 2001 - "Biobleaching of pulp with dioxygen in laccase-mediator system - effect of variables on the reaction kinetics”. J. Mol. Catal. B Enzym 16(3-4): 205-215.

Baldrian P. 2006 - "Fungal laccases-occurrence and properties.” FEMS microbiology reviews 30(2): 215-242.

Bankar SB, Bule MV, Singhal RS, Ananthanarayan L. 2009 - "Glucose oxidase - an overview". Biotechnol. Adv 27(4): 489-501.

Bayer EA, Belaich JP, Shoham Y, Lamed R. 2004 - The cellulosomes: multienzyme machines for degradation of plant cell wall polysaccharides. Annual Review of Microbiology. 58: 521554.

Bayer EA, Chanzy H, Lamed R, Shoham Y. 1998 - Cellulose, cellulases and cellulosomes. Current opinion in structural biology 8(5): 548-557.

Bayer EA, Morag E, Lamed R. 1994 - The cellulosome - a treasure-trove for biotechnology. Trends in biotechnology 12(9): 379-386.

Ben Hamman O, de la Rubia T, Martinez J. 1999 - The effect of manganese on the production of Phanerochaete $\mathrm{fl}$ avido-alba ligninolytic peroxidase in nitrogen limited cultures. FEMS Microbiology Letters. 177: 137-142.

Beulah D, Sunitha EM, Srilakshmi T. 2015 - Production, Purification And Assay of Pectinase Enzyme From Aspergillus niger. Helix 1: 673-U45.

Bhaskar N, Sudeepa ES, Rashmi HN, Tamil Selvi AT. 2007 - Partial purification and characterization of protease of Bacillus proteolyticus CFR3001 isolated from fish processing waste and its antibacterial activities. Bioresource Technology 98(14): 2758-2764.

Bhattacharya SS, Banerjee R. 2008 - Laccase mediated biodegradation of 2, 4-dichlorophenol using response surface methodology. Chemosphere 73(1): 81-85.

Birnbaum SM, Levintow L, Kingsley RB, Greenstein JP. 1952 - Specificity of amino acid acylases. Journal of Biological Chemistry 194(1): 455-470.

Birse CE, Clutterbuck AJ. 1990 - N-Acetyl-6-hydroxytryptophan oxidase, a developmentally controlled phenol oxidase from Aspergillus nidulans. The Journal of General Microbiology 136: $1725-1730$.

Bogan BW, Lamar RT. 1996 - Polycyclic aromatic hydrocarbon-degrading capabilities of Phanerochaete laevis HHB-1625 and its extracellular ligninolytic enzymes. Applied Environmental Microbiology 62: 1597-1603.

Bollag JM, Chu HL, Rao MA, Gianfreda L. 2003 - Enzymatic oxidative transformation of chlorophenol mixtures. Journal of environmental quality 32(1): 63-69.

Bollag JM, Myers C. 1992 - Detoxification of aquatic and terrestrial sites through binding of pollutants to humic substances. Science of the Total Environment 117: 357-366.

Bolli A, Galluzzo P, Ascenzi P, Del Pozzo G et al. 2008 - Laccase treatment impairs bisphenol A-induced cancer cell proliferation affecting estrogen receptor $\alpha$-dependent rapid signals. IUBMB life 60(12): 843-852.

Borglum GB, Sternberg MZ. 1972 - Properties of a fungal lactase.Journal of Food Science 37(4): 619-623.

Bourbonnais R, Paice MG, Reid ID, Lanthier P, Yaguchi M. 1995 - "Lignin oxidation by laccase isozymes from Trametes versicolor and role of the mediator 2, 2'-azinobis (3ethylbenzthiazoline-6-sulfonate) in kraft lignin depolymerization.” Applied and Environmental Microbiology 61(5): 1876-1880.

Budde CL, Beyer A, Munir IZ, Dordick JS, Khmelnitsky YL. 2001 - "Enzymatic nitration of phenols”. J. Mol. Catal. B Enzym 15(1-3): 55-64.

Carvalho LMJ, Deliza R, Silva CAB, Miranda RM, Maia MCA. 2003 - Identifying the adequate process conditions by consumers for pineapple juice using membrane technology. Journal of Food Technology 1(4): 150-156. 
Chakar FS, Ragauskas AJ. 2001 - Formation of quinonoid structures in laccase mediator reactions. In: Oxidative Delignification Chemistry: Fundamentals and Catalysis, D.S. Argyropoulos, ed. ACS Symposium Series 785. American Chemical Society, Washington, DC 444-456.

Chao YQ, Huang Y, Fei YH, Yang Q. 2008 - Tolerance and enzyme response of ectomycorrhizal fungi Xerocomus chrysenteron to DDT stress. Huan jing ke xue = Huanjing kexue/ [bian ji, Zhongguo ke xue yuan huan jing ke xue wei yuan hui "Huan jing ke xue" bian ji wei yuan hui.] 29(3): 788-794.

Chivukula M, Renganathan V. 1995 - Phenolic azo dye oxidation by laccase by Pyricularia oryzae. Applied Environmental Microbiology. 61: 4374-4377.

Colao MC, Lupino S, Garzillo AM, Buonocore V, Ruzzi M. 2006 - Heterologous expression of lcc1 gene from Trametes trogii in Pichia pastoris and characterization of the recombinant enzyme. Microbial Cell Factories 5(1): 31.

Collins PJ, Dobson AD. 1996 - "Oxidation of fluorene and phenanthrene by Mn (II) dependent peroxidase activity in whole cultures of Trametes (Coriolus) versicolor”. Biotechnol. Lett 18(7): 801-804.

Cook JN, Worsley JL. 1996 - “U.S. Patent No. 5,521,091. Washington, DC: U.S. Patent and Trademark Office".

Coutinho PM, Reilly PJ 1997 - Glucoamylase structural, functional, and evolutionary relationships. Proteins: Structure, Function, and Bioinformatics 29(3): 334-347.

Couto SR, Herrera, JLT. 2007- “Laccases in pollution control”. Ter Aquat Environ Tox, 1, 34-45.

Crini G, Lichtfouse E. 2019 - Advantages and disadvantages of techniques used for wastewater treatment. Environmental Chemistry Letters, 17(1), 145-155.

Cripps C, Bumpus JA, Aust SD. 1990 - Biodegradation of azo and heterocyclic dyes by Phanerochaete chrysosporium. Applied Environmental Microbiology. 56: 1114-1118.

Crueger W, Crueger A. 1984 - Enzymes. In Bio-Technology. A Text book of Industrial Microbiology. 161-186.

D’Annibale A, Stazi SR, Vinciguerra V, Sermanni GG. 2000 - Oxirane-immobilized Lentinula edodes laccase: stability and phenolics removal efficiency in olive mill wastewater. Journal of biotechnology 77(2): 265-273.

Dauber SR, Boehnke B. 1993 - German Patent DE-4141832.

Davila-Vazquez G, Tinoco R, Pickard MA, Vazquez-Duhalt R. 2005 - "Transformation of halogenated pesticides by versatile peroxidase from Bjerkandera adusta”. Enzyme Microb. Technol 36(2-3): 223-231.

Davis S, Burns RG. 1990 - Decolorization of phenolic effluents by soluble and immobilized phenol oxidases. Applied Microbiology Biotechnology 32: 721-726.

De Jong E, Van Berkel WJH, Van Der Zwan RP, De Bont JAM. 1992 - "Purification and characterization of vanillyl-alcohol oxidase from Penicillium simplicissimurn: a novel aromatic alcohol oxidase containing covalently bound FAD. European Journal of Biochemistry 208: 651-657

Dec J, Bollag JM. 2000 - Phenoloxidase-mediated interactions of phenols and anilines with humic materials. Journal of Environmental Quality 29(3): 665-676.

Deng A, Wu J, Zhang Y, Zhang G, Wen T. 2010 - Purification and characterization of a surfactantstable high-alkaline protease from Bacillus sp. B001. Bioresource Technology 101(18): 7100-7106.

Dezotti MLH, Innocentini-Mei, Duran N. 1995 - Silica immobilized enzyme catalyzed removal of chlorolignins from eucalyptus kraft effluent. Journal of Biotechnology. 43: 161-167.

Drauz K. 1997 - "Chiral amino acids: a versatile tool in the synthesis of pharmaceuticals and fine chemicals”. CHIMIA 51(6): 310-314.

Dutra JC, Terzi SDC, Bevilaqua JV, Damaso MC et al. 2008 - Lipase production in solid-state fermentation monitoring biomass growth of Aspergillus niger using digital image processing. Applied Biochemistry and Biotechnology 147(1-3): 63-75. 
Facchini FDA, Vici AC, Pereira MG, Jorge JA, de Moraes MDLT. 2016 - Enhanced lipase production of Fusarium verticillioides by using response surface methodology and wastewater pretreatment application. Journal of Biochemical Technology 6(3): 996-1002.

Fernández D, Russi S, Vendrell J, Monod M, Pallarès I. 2013 - A functional and structural study of the major metallo protease secreted by the pathogenic fungus Aspergillus fumigatus. Acta Crystallogr D Biol Crystallogr.

Ferreira VS, Magalhaes DB, Kling SH, da Silva JG, Jr Bon EPS. 2000 - N-demethylation of Methylene Blue by lignin peroxidase from Phanerochaete chrysosporium. Applied Biochemistry Biotechnology. 84-86: 255-265

Ferrer I, Dezotti M, Duran N. 1991 - Decolorization of kraft effl uent by free and immobilized lignin peroxidases and horseradish peroxidase. Biotechnology Letters.13: 577-582.

Field JA, de Jong E, Feijoo Costa G, de Bont JAM. 1992 - Biodegradation of polycyclic aromatic hydrocarbons by new isolates of white-rot fungi. Appllied. Environmental Microbiology. 58: 2219-2226.

Ford CI, Walter M, Northcott GL, Di HJ et al. 2007 - Fungal inoculum properties: extracellular enzyme expression and pentachlorophenol removal in highly contaminated field soils. Journal of environmental quality 36(6): 1599-1608.

Franken LPG, Marcon NS, Treichel H, Oliveira D et al. 2010 - Effect of treatment with compressed propane on lipases hydrolytic activity. Food and Bioprocess Technology 3(4): 511-520.

Fujimoto Z, Kaneko S, Kim WD, Park GG et al. 2009 - The tetramer structure of the glycoside hydrolase family $27 \alpha$-galactosidase I from Umbelopsis vinacea. Bioscience, biotechnology, and biochemistry 73(10): 2360-2364.

Galli E, Brancaleoni E, Di Mario F, Donati E et al. 2008 - Mycelium growth and degradation of creosote-treated wood by basydiomycetes. Chemosphere 72(7): 1069-1072.

Gibriel AY, Amin AA, Yassien NM, El Banna HA, Khaled FM. 2014 - Immobilization techniques for P. aculeatum dextranase. International Journal of Current Microbiology and Applied Sciences, 3, 1114-1134.

Gómez-Toribio V, Martínez AT, Martínez MJ, Guillén, F. 2001 - “Oxidation of hydroquinones by the versatile ligninolytic peroxidase from Pleurotus eryngii: $\mathrm{H} 2 \mathrm{O} 2$ generation and the influence of Mn2+”. Eur J Biochem 268(17): 4787-4793.

Gorbatova ON, Koroleva OV, Landesman EO, Stepanova EV, Zherdev AV. 2006 - Increase of the detoxification potential of basidiomycetes by induction of laccase biosynthesis. Applied Biochemistry and Microbiology 42(4): 414-419.

Grbavčić SŽ, Dimitrijević-Branković SI, Bezbradica DI, Šiler-Marinković SS, Knežević ZD. 2007 - Effect of fermentation conditions on lipase production by Candida utilis. Journal of the Serbian Chemical Society 72(8-9): 757-765.

Griebeler N, Polloni AE, Remonatto D, Arbter F et al. 2011 - Isolation and screening of lipaseproducing fungi with hydrolytic activity. Food and Bioprocess Technology 4(4): 578-586.

Guillen F, Martinez AT, Martinez MJ. 1992 - "Substrate specificity and properties of the aryl-alcohol oxidase from the ligninolytic fungus Pleurotus eryngii”. Eur J Biochem, 209(2): 603-611.

Gupta N, Sahai V, Gupta R. 2007 - Alkaline lipase from a novel strain Burkholderia multivorans: Statistical medium optimization and production in a bioreactor. Process Biochemistry 42(4): 518-526.

Gupta R, Beg Q, Khan S, Chauhan B. 2002 - An overview on fermentation, downstream processing and properties of microbial alkaline proteases. Applied microbiology and biotechnology 60(4): 381-395.

Haemmerli SD, Leisola MS, Sanglard D, Fiechter A. 1986 - “Oxidation of benzo (a) pyrene by extracellular ligninases of Phanerochaete chrysosporium. Veratryl alcohol and stability of ligninase”. J BIOL CHEM, 261(15): 6900-6903. 
Hansberg W, Salas-Lizana R, Domínguez L. 2012 -Fungal catalases: function, phylogenetic origin and structure. Archives of biochemistry and biophysics 525(2): 170-180.

Hatakka A. 1994 - Lignin-modifying enzymes from selected white-rot fungi: production and role in lignin degradation. FEMS Microbiol. Rev. 13: 125-135.

Heemken OP, Reincke H, Stachel B, Theobald N. 2001 - The occurrence of xenoestrogens in the Elbe river and the North Sea. Chemosphere 45(3): 245-259.

Heinfling-Weidtmann A, Reemtsma T, Storm T, Szewzyk U. 2001 - Sulfophthalimide as major metabolite formed from sulfonated phthalocyanine dyes by the white-rot fungus Bjerkandera adusta. FEMS Microbiol. Lett 203(2): 179-183.

Hema A, Ujjval T, Kamlesh P. 2006 - Alpha amylase production by Bacillus cereus MTCC 1305 using solid-state fermentation. Journal of Food Technology and Biotechnology 44(2): 241245

Hengge A. 1999 - Re: how is catalase used in industry?. General Biology. MadSci Network.

Henriksson G, Johansson G, Pettersson G. 2000 - A critical review of cellobiose dehydrogenases. Journal of Biotechnology. 78: 93-113.

Henson JM, Butler MJ, Day AW. 1999 - The dark side of the mycelium: melanins of phytopathogenic fungi. Annual review of phytopathology 37(1): 447-471.

Hermansyah H, Wijanarko A, Gozan M. 2007 - “Consecutive reaction model for triglyceride hydrolysis using lipase.” Jurnal Teknologi 2: 151-157.

Hofrichter M, Vares T, Scheibner K, Galkin S et al. 1999 - "Mineralization and solubilization of synthetic lignin (DHP) by manganese peroxidases Nematoloma frowardii and Phlebia radiate. Journal of Biotechnology 67: 217-228.

Hofrichter M. 2002 - "Review: lignin conversion by manganese peroxidase (MnP).” Enzyme and Microbial Technology. 30: 454-466.

Hooper NM. 2002 - "Proteases in Biology and Medicine.” London: Portland Press. ISBN 1-855781476

Hu X, Zhang Y, Zhao X, Hwang HM. 2007 - "Biodegradation of benzo [a] pyrene with immobilized laccase: genotoxicity of the products in HaCat and A3 cells.” Environmental and molecular mutagenesis 48(2), pp.106-113.

Hublik G, Schinner F. 2000 - "Characterization and immobilization of the laccase from Pleurotus ostreatus and its use for the continuous elimination of phenolic pollutants”. Enzyme Microb. Technol 27(3-5): 330-336.

Hwang KY, Song HK, Chang C, Lee J et al. 1997 - "Crystal structure of thermostable alphaamylase from Bacillus licheniformis refined at 1.7 A resolution.” Molecules and cells, 7(2): 251-258.

Jecu L, Gheorghe A, Rosu A, Raut I et al. 2010 - "Ability of fungal strains to degrade PVA based materials.” Journal of Polymers and the Environment 18(3): 284-290.

Jeffers MR, McRoberts WC, Harper, DB. 1997 - "Identification of a phenolic 3-Omethyltransferase in the lignin-degrading fungus Phanerochaete chrysosporium”. Microbiology, 143(6): 1975-1981.

Jellouli K, Bougatef A, Manni L, Agrebi R et al. 2009 - "Molecular and biochemical characterization of an extracellular serine-protease from Vibrio metschnikovii J1.” Journal of industrial microbiology \& biotechnology 36(7): 939-948.

Johannes C, Majcherczyk A, Huttermann A. 1996 - "Degradation of anthracene by laccase of Trametes versicolor in the presence of different mediator compounds.” Applied Microbiology and Biotechnology. 46: 313-317.

Joo SS, Ryu IW, Park JK, Yoo YM et al. 2008 - "Molecular cloning and expression of a laccase from Ganoderma lucidum, and its antioxidative properties.” Molecules \& Cells (Springer Science \& Business Media BV) 25(1).

Joseph B, Ramteke PW, Thomas G. 2008 - "Cold active microbial lipases: some hot issues and recent developments.” Biotechnology advances 26(5): 457-470. 
Junghanns C, Moeder M, Krauss G, Martin C, Schlosser D. 2005 - Degradation of the xenoestrogen nonylphenol by aquatic fungi and their laccases. Microbiology 151(1): 45-57.

Kadri T, Rouissi T, Brar SK, Cledon M et al. 2017 - Biodegradation of polycyclic aromatic hydrocarbons (PAHs) by fungal enzymes: A review. Journal of environmental sciences, 51, $52-74$.

Kapich AN, Steffen KT, Hofrichter M, Hatakka A. 2005 - "Involvement of lipid peroxidation in the degradation of a non-phenolic lignin model compound by manganese peroxidase of the litter-decomposing fungus Stropharia coronilla”. BIOCHEM BIOPH RES CO, 330(2): 371377.

Kashyap DR, Vohra PK, Chopra S, Tewari R. 2001 - "Applications of pectinases in the commercial sector: a review.” Bioresource technology 77(3): 215-227.

Kauffmann C, Petersen BR, Bjerrum MJ. 1999 - "Enzymatic removal of phenols from aqueous solutions by Coprinus cinereus peroxidase and hydrogen peroxide”. J. Biotechnol. 73(1): 7174.

Kim JS, Park JW, Lee SE, Kim JE. 2002 - "Formation of bound residues of 8-hydroxybentazon by oxidoreductive catalysts in soil.” Journal of Agricultural and Food Chemistry 50 (12): 35073511.

Kim KK, Song HK, Shin DH, Hwang KY, Suh SW. 1997 - "The crystal structure of a triacylglycerol lipase from Pseudomonas cepacia reveals a highly open conformation in the absence of a bound inhibitor”. Structure 5(2): 173-185.

Kirk TK, Connors WJ, Zeikus JG. 1976 - Requirement for a growth substrate during lignin decomposition by two wood-rotting fungi. Applied and Environmental Microbiology, 32(1), pp.192-194.

Kirk TK, Cullen D. 1998 - "Enzymology and molecular genetics of wood degradation by white rot fungi.” In: Environmentally Friendly Technologies for the Pulp and Paper Industry, R.A. Young and M. Akhtar, eds. Wiley, New York: 273-308.

Kocher GS, Mishra S. 2009 - "Immobilization of Bacillus circulans MTCC 7906 for enhanced production of alkaline protease under batch and packed bed fermentation conditions." Internet Journal of Microbiology 7(2): 359-378.

Koschorreck K, Richter SM, Swierczek A, Beifuss U et al. 2008 - "Comparative characterization of four laccases from Trametes versicolor concerning phenolic $\mathrm{C}-\mathrm{C}$ coupling and oxidation of PAHs.” Archives of biochemistry and biophysics 474(1): 213-219.

Krop JJP, Pilnik W. 1974 - Cloud loss studies in citrus juices: cloud stabilization by a yeastpolygalacturonase. LWT Lebensmitt Wissensch Technol.

Kües U. 2015 - Fungal enzymes for environmental management. Current opinion in biotechnology, 33, 268-278.

Kuhad RC, Gupta R, Singh A. 2011 - 'Microbial cellulases and their industrial applications". Enzyme Res, 2011. 280696. Doi:10.4061/2011/280696

Kumar P, Satyanarayana T. 2009 - "Microbial glucoamylases: characteristics and applications". CRIT REV BIOTECHNOL 29(3): 225-255.

Langholm Jensen J, Mølgaard A, Navarro Poulsen JC, Harboe MK et al. 2013 - Camel and bovine chymosin: the relationship between their structures and cheese-making properties. Acta Crystallographica Section D: Biological Crystallography 69(5): 901-913.

Larsson AM, Andersson R, Ståhlberg J, Kenne L, Jones TA. 2003 - "Dextranase from Penicillium minioluteum: reaction course, crystal structure, and product complex”. Structure 11(9): 11111121.

Leontievsky AA, Myasoedova NM, Baskunov BP, Evans CS, Golovleva LA. 2000 "Transformation of 2, 4, 6-trichlorophenol by the white rot fungi Panus tigrinus and Coriolus versicolor”. Biodegradation 11(5): 331-340.

Littlechild JA 2015 - "Enzymes from extreme environments and their industrial applications". FRONT BIOENG BIOTECH 3: 161. 
Lobos S, Larram J, Salas L, Cullen D, Vicuna R. 1994 - “Isoenzymes of manganese dependent peroxidase and laccase produced by the lignin degrading basidiomycete Ceriporiopsis subvermispora.” Microbiology 14: 2691-2698.

Lopez C, Mielgo I, Moreira MT, Feijoo G, Lema JM. 2002 - "Enzymatic membrane reactors for biodegradation of recalcitrant compounds.” Journal of Biotechnology. 99: 249-257.

Mahmoud GAE, Koutb MM, Morsy FM, Bagy MM. 2015 - "Characterization of lipase enzyme produced by hydrocarbons utilizing fungus Aspergillus terreus.” European Journal of Biological Research 5(3): 70-77.

Margesin R, Zimmerbauer A, Schinner F. 1999 - "Soil lipase activity - A useful indicator of oil biodegradation.” Biotechnology Techniques 13(12): 859-863.

Martin C, Christopher B. 1990 Enzyme technology.

Maté MJ, Zamocky M, Nykyri LM, Herzog C et al. 1999 - "Structure of catalase-A from Saccharomyces cerevisiae”. J. Mol. Biol 286(1): 135-149.

Matsubara M, Lynch JM, De Leij FAAM. 2006 - "A simple screening procedure for selecting fungi with potential for use in the bioremediation of contaminated land.” Enzyme and Microbial Technology 39(7): 1365-1372.

Mauti GO, Onguso J, Kowanga, DK Mauti EM. 2016 - "Biodegradation activity of Aspergillus niger Lipase isolates from a Tropical Country Garage.” Journal of Scientific and Innovative Research 5(1): 15-18.

Mayans O, Scott M, Connerton I, Gravesen T et al. 1997 - "Two crystal structures of pectin lyase A from Aspergillus reveal a $\mathrm{pH}$ driven conformational change and striking divergence in the substrate-binding clefts of pectin and pectate lyases." Structure 5(5): 677-689.

Mc Feeters RF. 1985 - "Changes in pectin and cellulose during processing." Chemical changes in food during processing 347-372.

Mehaia MA, Cheryan M. 1987 - "Production of lactic acid from sweet whey permeate concentrates.” Process biochemistry 22(6): 185-188.

Mendonça RT, Jara JF, González V, Elissetche JP, Freer J. 2008 - "Evaluation of the white-rot fungi Ganoderma australe and Ceriporiopsis subvermispora in biotechnological applications.” Journal of industrial microbiology \& biotechnology 35(11): 1323.

Mertens JA, Skory CD. 2007 - "Isolation and characterization of a second glucoamylase gene without a starch binding domain from Rhizopus oryzae.” Enzyme and microbial technology 40(4): 874-880.

Messias JM, da Costa BZ, de Lima VM, Dekker RF et al. 2009 - "Screening Botryosphaeria species for lipases: Production of lipase by Botryosphaeria ribis EC-01 grown on soybean oil and other carbon sources”. Enzyme Microb. Technol 45(6-7): 426-431.

Michel FC, Jr Dass SB, Grulke EA, Reddy CA. 1991 - "Role of manganese peroxidases and lignin proxidases of Phanerochaete chrysosporium in the decolorization of kraft bleach plant effluent.” Applied Environmental Microbiology. 57: 2368-2375.

Moldes M, Zuo Y, Morrison RF, Silva D et al. 2003 - "Peroxisome-proliferator-activated receptor $\gamma$ suppresses Wnt/ $\beta$-catenin signalling during adipogenesis”. BIOCHEM J 376(3): 607-613.

Muñoz IG, Mowbray SL, Ståhlberg J. 2003 - "The catalytic module of Cel7D from Phanerochaete chrysosporium as a chiral selector: structural studies of its complex with the beta blocker (R)propranolol”. ACTA CRYSTALLOGR D 59(4): 637-643.

Nicell JA, Al-Kassim L, Bewtra JK, Taylor KE. 1993 - "Wastewater treatment by enzyme catalyzed polymerization and precipitation.” Biodeterioration. Abstr. 7: 1-7.

Nie G, Reading NS, Aust SD. 1999 - "Relative stability of recombinant versus native peroxidases from Phanerochaete chrysosporium.” Archives of Biochemistry and Biophysics. 365: 328334.

Niku-Paavola ML, Viikari L. 2000 - “Enzymatic oxidation of alkenes.” Journal of Molecular Catalysis B: Enzymatic 10(4): 435-444.

Niyonzima F, More S. 2014 - "Biochemical properties of the alkaline lipase of Bacillus flexus XJU-1 and its detergent compatibility.” Biologia 69(9): 1108-1117. 
Ollikka P, Alhonmaki K, Leppanen VM, Glumoff T et al. 1993 - "Decolorization of azo, triphenyl methane, heterocyclic, and polymeric dyes by lignin peroxidase isoenzymes from Phanerochaete chrysosporium.” Applied Environmental Microbiology. 59: 4010-4016

Oseni OA. 2011 - "Production of microbial protease from selected soil fungal isolates." Nigerian Journal of Biotechnology 23.

Paice MG, Archibald FS, Bourbonnais R, Jurasek L et al. 1996 - In: ACS Symp. Ser. 655. Enzymes for Pulp and Paper Processing. Eds. T.W. Jeffries and L. Viikari. ACS, Washington DC 1996, 151-164.

Pandey A, Soccol CR, Nigam P, Soccol VT et al. 2000 - "Biotechnological potential of agroindustrial residues. II: cassava bagasse.” Bioresource technology 74(1): 81-87.

Park H, Lee KS, Chi YM, Jeong SW. 2005 - "Effects of methanol on the catalytic properties of porcine pancreatic lipase.” Journal of microbiology and biotechnology 15(2): 296-301.

Pearce KAREN, Ollermann RA. 1998 - "Status and scope of bioremediation in South Africa." Bioremediation: Principles and Practice-Bioremediation Technologies 3: 155-182.

Pickard MA, Roman R, Tinoco R, Vazquez-Duhalt R. 1999 - "Polycyclic aromatic hydrocarbon metabolism by white rot fungi and oxidation by Coriolopsis gallica UAMH 8260 laccase". Appl. Environ. Microbiol 65(9): 3805-3809.

Pointing S. 2001 - "Feasibility of bioremediation by white-rot fungi.” Applied microbiology and biotechnology 57(1): 20-33.

Pointing SB, Vrijmoed LLP. 2000 - "Decolorization of azo and triphenylmethane dyes by Pycnosporus sanguineus producing laccase as the sole phenoloxidase." World Journal of Microbiology and Biotechnology. 16: 317-318

Pomeranz Y, Miller BS. 1963 - "Evaluation of lactase preparations for use in bread-making." Journal of Agricultural and Food Chemistry.11: 19.

Poots VJP, Mckay G, Healy JJ. 1976 - "The removal of acid dye from effluent using natural adsorbents - I peat.” Water research 10(12): 1061-1066.

Pozdnyakova NN, Rodakiewicz-Nowak J, Turkovskaya OV. 2004 - "Catalytic properties of yellow laccase from Pleurotus ostreatus D1.” Journal of Molecular Catalysis B: Enzymatic 30(1): $19-24$.

Prasad MP, Manjunath K. 2011 - "Comparative study on biodegradation of lipid-rich wastewater using lipase producing bacterial species.” Indian Journal of Biotechnology 10 (1): 121-124.

Quintella CM, Mata AM, Lima LC. 2019 - Overview of bioremediation with technology assessment and emphasis on fungal bioremediation of oil contaminated soils. Journal of environmental management, 241, 156-166.

Raghukumar C. 2000 - "Fungi from marine habitats: an application in bioremediation - II, Contribution No. 3538 of the National Institute of Oceanography.” Mycological research 104(10): 1222-1226.

Rama R, Mougin C, Boyer FD, Kollmann A et al. 1998 - "Biotransformation of benzo[a]pyrene in bench scale reactor using laccase of Pycnosporus cinnabarinus.” Biotechnology Letters. 20: 1101-1104.

Rehman A, Shakoori AR. 2001 - "Heavy metal resistance Chlorella spp., isolated from tannery effluents, and their role in remediation of hexavalent chromium in industrial waste water." Bulletin of environmental contamination and toxicology 66(4): 542-547.

Rhodes CJ. 2012 - "Feeding and healing the world: through regenerative agriculture and permaculture.” Science progress 95(4): 345-446.

Rhodes CJ. 2013 - “Applications of bioremediation and phytoremediation.” Science progress 96(4): 417-427.

Rhodes CJ. 2014 - "Mycoremediation (bioremediation with fungi)-growing mushrooms to clean the earth.” Chemical Speciation \& Bioavailability 26(3): 196-198.

Ricupito A, Del Pozzo G, Diano N, Grano V et al. 2009 - "Effect of bisphenol A with or without enzyme treatment on the proliferation and viability of MCF-7 cells." Environment international 35(1): 21-26. 
Riffaldi RR, Levi-Minzi R, Cardelli R, Palumbo S, Saviozzi A. 2006 - "Soil biological activities in monitoring the bioremediation of diesel oil-contaminated soil.” Water, Air, and Soil Pollution 170 (1-4): 3-15.

Riva S. 2006 "Laccases: blue enzymes for green chemistry." TRENDS in Biotechnology 24(5): 219-226.

Rodriguez J, Corbel S, Hannikainen DC, Belloni T et al. 2004 - "Spectral properties of lowfrequency quasi-periodic oscillations in GRS 1915+ 105”. ap jay 615(1): 416.

Roper JC, Sarkar JM, Dec J, Bollag JM. 1995 - "Enhanced enzymatic removal of chlorophenols in the presence of co-substrates.” Water Research 29: 2720-2724.

Salgado JM, Abrunhosa L, Venâncio A, Domínguez JM, Belo I. 2016 - "Combined bioremediation and enzyme production by Aspergillus sp. in olive mill and winery wastewaters." International Biodeterioration \& Biodegradation 110: 16-23.

Sampey JJ, Neubeck CE 1955 - "Low lactose concentrate makes better ice cream.” Food Eng 27: 68.

Saranraj P, Stella D. 2013 - “Fungal amylase—a review.” International Journal of Microbiological Research 4(2): 203-211.

Sato T, Tosa T. 2010 - "L-Amino Acids Production by Aminoacylase.” Encyclopedia of Industrial Biotechnology.

Sayadi S, Ellouz R. 1995 - "Roles of lignin peroxidase and manganese peroxidase from Phanerochaete chrysosporium in the decolorization of olive mill waste waters." Applied Environmental Microbiology. 61: 1098-1103.

Setti L, Giuliani S, Spinozzi G, Pifferi PG. 1999 - "Laccase catalyzed-oxidative coupling of 3methyl 2-benzothiazolinone hydrazone and methoxyphenols." Enzyme and Microbial Technology 25(3): 285-289.

Sharma D, Sharma B, Shukla AK. 2011 - "Biotechnological approach of microbial lipase: a review.” Biotechnology 10 (1): 23-40.

Singh N, Kayastha AM. 2013 - "A novel application of Cicer $\alpha$-galactosidase in reduction of raffinose family oligosaccharides in soybean flour”. J PLANT BIOCHEM BIOT 22(3): 353356.

Steffen K, Hofrichter M, Hatakka A. 2000 - "Mineralization of 14C-labelled synthetic lignin and ligninolytic enzyme activities of litter-decomposing basidiomycetous fungi." Applied Microbiology and Biotechnology. 54: 819-825.

Stimpson EG. 1954 - Frozen concentrated milk products. U.S. Patent 2.668,765.

Stimpson EG. 1957 - Lactase-hydrolyzed lactase in feed. U.S. Patent 2.781.266.

Susmitha S, Ranganayaki P, Vidyamol KK, Vijayaraghavan R. 2013 - "Purification and characterization of Catalase enzyme from Agaricus bisporus.” International Journal of Current Microbiology and Applied Sciences. 2: 255-263.

Tekere M, Read JS, Mattiasson B. 2007 - "Polycyclic aromatic hydrocarbon biodegradation by a subtropical white rot fungus in packed bed and suspended carrier bioreactor systems.” Environmental Technology 28(6): 683-691.

ten Have R, Hartmans S, Teunissen PJM, Field JA. 1998 - "Purification and characterization of two lignin peroxidase isozymes produced by Bjerkandera sp. strain BOS55.” FEBS Lett. 422: 391-394.

Thakur S. 2012 - “Lipases, its sources, properties and applications: A review.” Int J Sci Eng Res 3(7): 1-29.

Thurston CF. 1994 - “The structure and function of fungal laccases.” Microbiology 140(1): 19-26.

Tien M, Kirk TK. 1983 - "Lignin-degrading enzyme from the hymenomycete Phanerochaete chrysosporium Burds”. Science, 221(4611): 661-663.

Torres E, Bustos-Jaimes I, Le Borgne S. 2003 - "Potential use of oxidative enzymes for the detoxification of organic pollutants.” Applied Catalysis B: Environmental 46(1): 1-15.

Tripathi AK, Harsh NSK, Gupta N. 2007 - "Fungal treatment of industrial effluents: a minireview.” Life Science Journal 4(2): 78-81. 
Ullah MA, Bedford CT, Evans CS. 2000 - "Reactions of pentachlorophenol with laccase from Coriolus versicolor.” Applied. Microbiology and Biotechnology 53: 230-234.

Urzua U, Larrondo L, Lobos S, Larrain J, Vicuna R. 1995 - “Oxidation reactions catalyzed by manganese peroxidase isoenzymes from Cerioporiopsis subvermispora." FEMS Microbiology Letters. 371: 132-136.

Ute S, Fritsche W. 1997 - "Enhancement of pyrene mineralization in soil by wood-decaying fungi”. FEMS Microbiol. Ecol 22(1): 77-83.

van Santen Y, Benen JA, Schröter KH, Kalk KH et al. 1999 - "1.68- $\AA$ Crystal Structure of Endo polygalacturonase II from Aspergillus niger and Identification of Active Site Residues by Site-directed Mutagenesis.” Journal of Biological Chemistry 274(43): 30474-30480.

Vares T, Hatakka A. 1997 - "Lignin-degrading activity and ligninolytic enzymes of different white-rot fungi: effects of manganese and malonate." Canadian Journal of Botany. 75: 61-71.

Vares T, Lundell TK, Hatakka A. 1992 - "Novel heme-containing enzyme possibly involved in lignin degradation by the white-rot fungus Junghuhnia separabilima.” FEMS Microbiology Letters. 99: 53-58.

Vares T, Lundell TK, Hatakka A. 1993 - "Production of multiple lignin peroxidases by the whiterot fungus Phlebia ochraceofulva.” Enzyme and Microbial Technology. 15: 664-669.

Venkatesagowda B, Ponugupaty E, Barbosa AM, Dekker RFH. 2012 - "Diversity of plant oil seedassociated fungi isolated from seven oil-bearing seeds and their potential for the production of lipolytic enzymes.” World Journal of Microbiology and Biotechnology. 28: 71-80.

Viswanath B, Rajesh B, Janardhan A, Kumar AP, Narasimha G. 2014 - "Fungal laccases and their applications in bioremediation”. Enzyme research, 2014. ID163242: 21 pages

Viswanath B, Subhosh Chandra M, Pallavi H, Rajasekhar Reddy B. 2008 - "Screening and assessment of laccase producing fungi isolated from different environmental samples." African Journal of Biotechnology 7(8): 1129-1133.

Wang J, Tao Y, 2001 - "Biosorption of Chromium (VI) Ions from Aqueous Solution by a Novel Bacterial Exopolymers [J].” Technology of Water Treatment 3.

Wang W, Zhou W, Li J, Hao D et al. 2015 - "Comparison of covalent and physical immobilization of lipase in gigaporous polymeric microspheres.” Bioprocess and biosystems engineering 38(11): 2107-2115.

Wannstedt C, Rotella D, Siuda JF. 1990 - "Chloroperoxidase mediated halogenation of phenols". Benviron contam tox 44(2): 282-287.

Wohlfahrt G, Witt S, Hendle J, Schomburg D et al. 1999 - "1.8 and $1.9 \AA$ Å resolution structures of the Penicillium amagasakiense and Aspergillus niger glucose oxidases as a basis for modelling substrate complexes.” Acta Crystallographica Section D: Biological Crystallography 55(5): 969-977.

Wong CM, Wong KH, Chen XD. 2008 - "Glucose oxidase: natural occurrence, function, properties and industrial applications.” Applied microbiology and biotechnology 78(6): 927-938.

Wu F, Ozaki H, Terashima Y, Imada T, Ohkouchi Y. 1996 - “Activities of ligninolytic enzymes of the white rot fungus, Phanerochaete chrysosporium and its recalcitrant substance degradability.” Water Science Technology. 34: 69-78.

Xu F. 1996 - "Oxidation of phenols, anilines, and benzenethiols by fungal laccases: correlation between activity and redox potentials as well as halide inhibition.” Biochemistry 35(23): 7608-7614.

Yadav S, Yadav PK, Yadav D, Yadav KDS. 2009 - “Pectin lyase: a review.” Process Biochemistry 44(1): 1-10.

Yaver DS, Berka RM, Brown SH, Xu F. 2001 - “The presymposium on recent advances in lignin biodegradation and biosynthesis”. Vikki Biocentre, University of Helsinki, Finland, 40.

Ying GG, Williams B, Kookana R. 2002 - "Environmental fate of alkylphenols and alkylphenol ethoxylates - a review.” Environment international 28(3): 215-226.

Young L, Yu J. 1997 - “Ligninase-catalyzed decolorization of synthetic dyes.” Water Research 31: 1187-1193. 
Zhao J, Kwan HS. 1999 - "Characterization, molecular cloning, and differential expression analysis of laccase genes from the edible mushroom Lentinula edodes.” Appl. Environ. Microbiol 65(11): 4908-4913. 